\title{
INFORMATION LITERACY OF MANAGERS: MODELS AND FACTORS
}

\author{
Vladimír BOLEK $^{*}$, Mojmír KOKLES, Anita ROMANOVÁ ${ }^{(D)}$, \\ Michal ZELINA \\ Department of Information Management, Faculty of Business Management, \\ University of Economics in Bratislava, Bratislava, Slovak Republic
}

Received 19 December 2017; accepted 14 November 2018

\begin{abstract}
Participation in the information society means faster communication, development of new ideas, more creative ideas and education in terms of lifelong learning. The information society is a reality and a dominant element of politics in all developed countries of the world. Information literacy deals with the human ability to work effectively in the information society. Information literacy needs to be understood in a wider context, rather than only in terms of IT skills and abilities. The article compares and defines the concept of information literacy. It compares selected information literacy models. The starting point is a survey conducted among business managers in the Slovak Republic examining the level of information literacy of managers. The findings identify factors affecting the aggregate index of information literacy of managers and the proposed quantitative and qualitative model of the information literacy of managers. Presented are the unique results of long-term research on information and digital literacy in the Slovak Republic (Central Europe, the European Union and V4-Visegrad countries). So far, no research has been conducted focusing on the level of digital literacy of business managers and an information literacy model that would contribute to raising their level.
\end{abstract}

Keywords: digital literacy, information literacy, managers, lifelong learning, digital competencies, digital skills.

JEL Classification: M12, M15.

\section{Introduction}

Business economics is characterised by a large proportion of managers and other employees using information and communication technologies to perform their job tasks. Each organisation strives to achieve progress, development and prosperity. These aims are effective when meeting organisations' conditions that the managers with knowledge and technical literacy will control the organisations and make decisions. Regarding complexity and increasing

${ }^{\star}$ Corresponding author. E-mail: vladimir.bolek@euba.sk 
acceleration of changes in the information society, a demand for managers with high quality skills and effective use of knowledge is growing. Organisations require people who handle changing situations, unexpected changes and know how to cope with them quickly.

The aim of this study is to design a quantitative and qualitative information literacy model of a specific group (of managers). The article compares and defines in Chapter 1 the concept of information literacy. It compares selected information literacy models. Based on the seven proposed areas, we point out the character of models, homogeneous and heterogeneous features. After years of digital literacy research and factors influencing the literacy level of this specific group, there is a suggested model that leads to an increase in the level of information literacy. The research has set out relation research questions that examine the relationship of selected factors to the level of information literacy. They were factors that are supported by relevant literature, which is presented in Table 1. The research question was also set to analyse selected stimuli that influence approaches to education of ICT managers. As individual research questions are based on a detailed analysis of the theoretical basis, they are explained in the Literature review. Chapter 2 contains the methodology, the construction of an indicator for the measurement of information literacy, the structure of the research sample and the methods used. The impact of selected factors on information literacy and incentives on managers' training is addressed in Chapter 3. The results of the research carried out resulted in the drafting of an original qualitative model of managers' information literacy, which is included in Chapter 4. At the same time, research results are confronted with findings from other authors.

\section{Literature review}

The concept of information literacy was used for the first time in 1974 by Paul Zurkowski, the former president of the Information Industry Association. In his understanding those individuals can be considered information literate "who in the solution of problems have learned to use a wide range of techniques and information tools as well as primary resources" (Dombrovská, Landová, \& Tichá, 2004). The term itself formed gradually and in the mid1970s the concept of computer literacy appeared, but it was considered a subordinate concept of information literacy. Subsequently, in 1986, William Demo developed a definition that Martin Tessmer pronounced a year later: "Information literacy is the ability to effectively search and evaluate information related to a particular need" (Behrens, 1994). William Demo also specified individual components of information literacy. During this period, none of the authors dealing with information literacy have determined specific skills in working with ICTs. The specification of these skills emerged with the onset of development of new information technologies. Only the perspective of Jan Olsen and Bilal Coons of information literacy already includes the concept of information technologies. The concept of information literacy is currently clearly related to skills and abilities in the field of information technologies. Often, its characteristics are limited to the ability to work with computers and the internet. Information literacy should be understood in broader terms. The most commonly presented definition is by the American Library Association [ALA] (2000), namely: "Information literacy is a set of skills that require individuals to know when information is needed 
and an individual has the ability to find, evaluate, and effectively use the necessary information". Individual views and their content parallel uncover the wide spectrum of content of the information literacy focus as well as areas that go beyond. After evaluating individual views, we define the concept of information literacy as follows (Bolek, Kokles, \& Korček, 2016): Information literacy is defined as the ability to identify the need for information, to search for, obtain, process information available through appropriate ICT tools, evaluate it and use the obtained information as efficiently as possible. Information literacy generally includes the ability to understand information and use it in various formats from different sources presented through modern ICTs.

There are several factors influencing the literacy level, the justification of which we have explored in this article (Table 1).

Table 1. Comparison of relevant literature (source: own processing)

\begin{tabular}{|l|l|}
\hline \multicolumn{1}{|c|}{ Factors } & \multicolumn{1}{c|}{ Relevant literature } \\
\hline $\begin{array}{l}\text { ICT position in an } \\
\text { enterprise }\end{array}$ & $\begin{array}{l}\text { (Cuadrado-Roura \& Tabuenca, 2006; Barba-Sánchez, del Pilar Martínez- } \\
\text { Ruiz, \& Jiménez-Zarco, 2007; Saarenketo, Puumalainen, Kyläheiko, \& Kuiv- } \\
\text { alainen, 2008; Antlová, 2009; Modimogale \& Jan, 2011; Ongori \& Migiro, } \\
\text { 2010; Manochehr, Al-Esmail, \& Ashrafi, 2012) }\end{array}$ \\
\hline $\begin{array}{l}\text { Intensity of ICT use } \\
\text { by managers in an } \\
\text { enterprise }\end{array}$ & $\begin{array}{l}\text { (Corso, Martini, Paolucci, \& Pellegrini, 2003; Acar, Kocak, Sey, \& Arditi, } \\
\text { 2005; Fuchs, Höpken, Föger, \& Kunz, 2010; Ongori \& Migiro, 2010) }\end{array}$ \\
\hline $\begin{array}{l}\text { Reducing financial } \\
\text { costs }\end{array}$ & $\begin{array}{l}\text { (De Silva \& Ratnadiwakara, 2008; Kpodar \& Andrianaivo, 2011; Sassi \& } \\
\text { Goaied, 2013; Kllı̧aslan, Sickles, Atay Kayış, \& Üçdoğruk Gürel, 2017) }\end{array}$ \\
\hline $\begin{array}{l}\text { Improving business } \\
\text { processes }\end{array}$ & (Ongori \& Migiro, 2010) \\
\hline Financial evaluation & (Lăzăroiu, 2015) \\
\hline $\begin{array}{l}\text { Increasing labour } \\
\text { productivity }\end{array}$ & $\begin{array}{l}\text { (Ceccobelli, Gitto, \& Mancuso, 2012; Cardona, Kretschmer, \& Strobel, } \\
\text { 2013; Spiezia, 2013; Kllıçaslan et al., 2017) }\end{array}$ \\
\hline Interest in ICT trends & $\begin{array}{l}\text { (White, 2008; Wermann, Kliesing, Colombo, \& Moraes, 2015; Majumdar, } \\
\text { 2015; Schrum et al., 2015; El Kadiri et al., 2016) }\end{array}$ \\
\hline Attitude towards ICT & $\begin{array}{l}\text { (Shaw \& Marlow, 1999; Southern \& Tilley, 2000; Ritchie \& Brindley, 2005; } \\
\text { Fulantelli \& Allegra, 2003; Fu, 2013) }\end{array}$ \\
\hline
\end{tabular}

From the literature and scientific researches, which are outlined in Tables 1 and 2, two important questions remain unanswered. It is the relationship between factors and information literacy and the relationship between incentives and access to education. Both questions also have a high practical significance and the responses to them are practically applicable in modern enterprise management. Therefore, we have identified the research questions as follows:

RQ1: as individual factors (ICT position, Intensity, Finance, Processes, Evaluation, Productivity, Trends, Attitude, Size), they influence the information literacy of managers, expressed by the summary index of information literacy (AIL).

RQ2: what incentives (interest in personal growth, career development, employers' requirements, interest in new trends in ICT, better pay, recommendation by an acquaintance) influence access to education of ICT managers. 


\begin{tabular}{|c|c|c|c|c|c|c|}
\hline 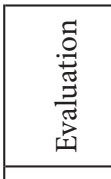 & \multirow[b]{2}{*}{ 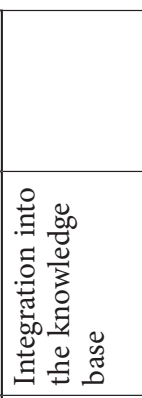 } & \multirow{2}{*}{ 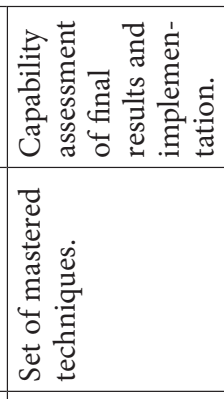 } & \multicolumn{2}{|c|}{ 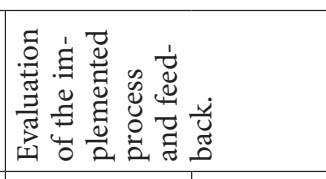 } & \multirow{2}{*}{ 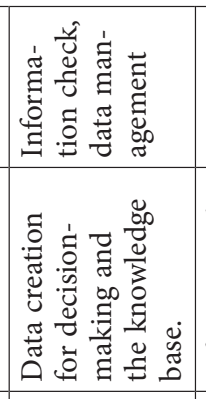 } & \multirow{2}{*}{ 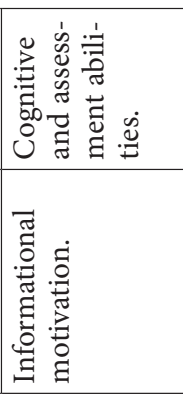 } \\
\hline 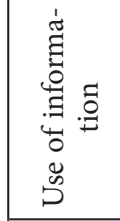 & & & 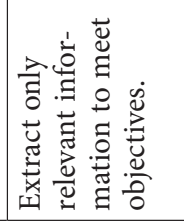 & 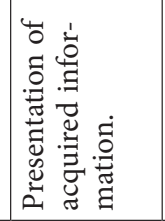 & & \\
\hline 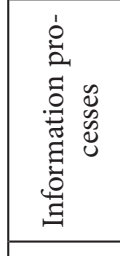 & 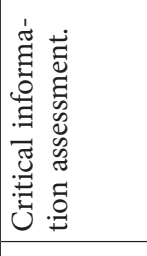 & 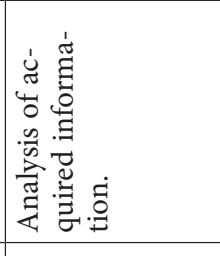 & 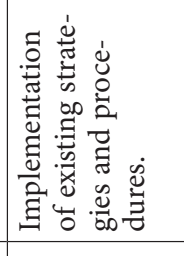 & 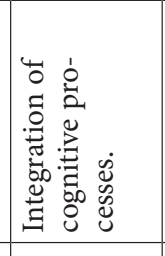 & 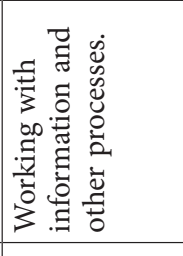 & 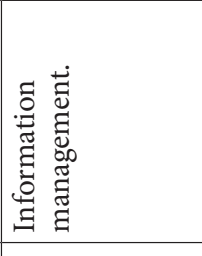 \\
\hline 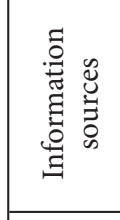 & & 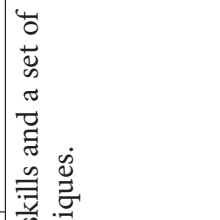 & 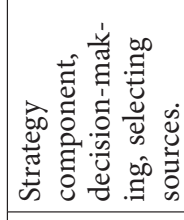 & 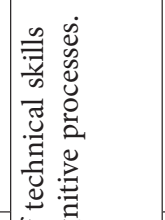 & 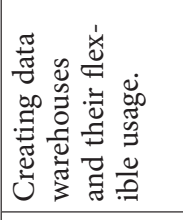 & \\
\hline 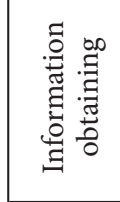 & 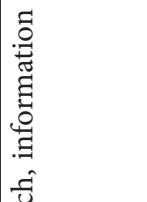 & 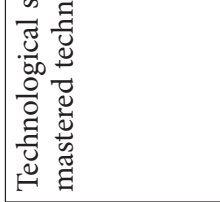 & 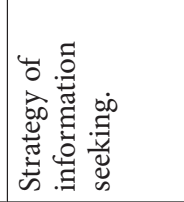 & 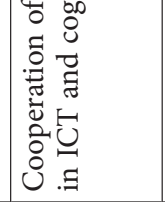 & 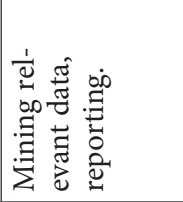 & 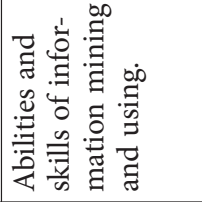 \\
\hline 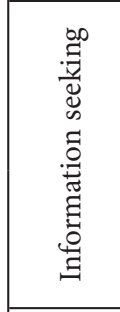 & 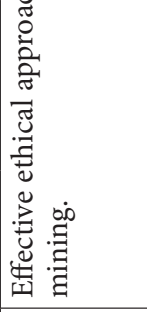 & 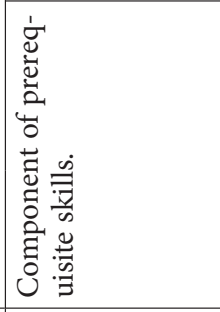 & 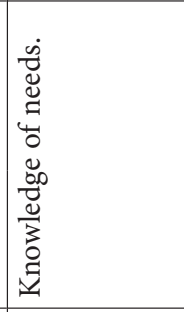 & 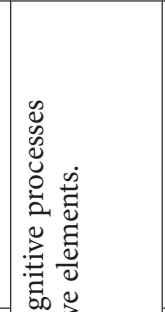 & 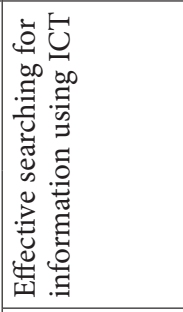 & \\
\hline 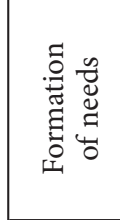 & 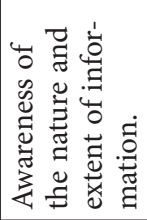 & 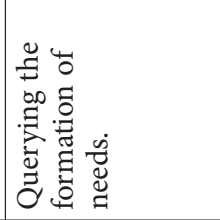 & 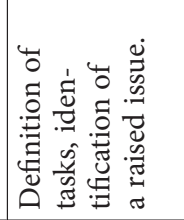 & 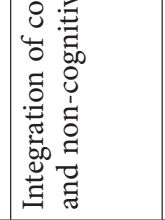 & 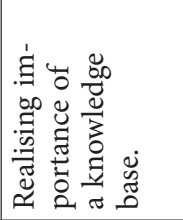 & 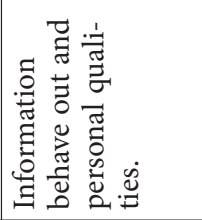 \\
\hline 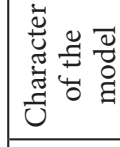 & \multicolumn{2}{|l|}{ 岗 } & \multicolumn{2}{|l|}{ 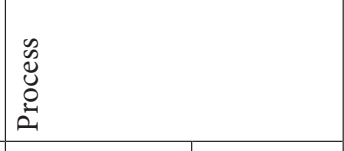 } & \multicolumn{2}{|l|}{ 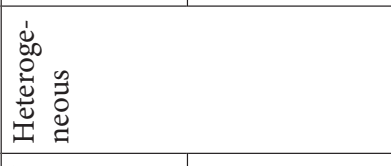 } \\
\hline $\begin{array}{l}\frac{\vec{v}}{0} \\
\frac{0}{4}\end{array}$ & 氦 & 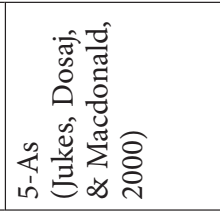 & 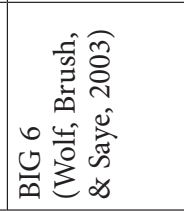 & 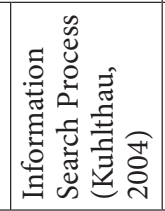 & 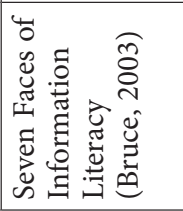 & 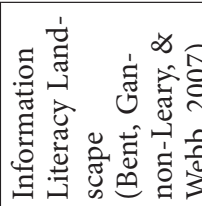 \\
\hline
\end{tabular}




\begin{tabular}{|c|c|c|c|c|}
\hline 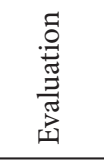 & \multicolumn{2}{|l|}{ 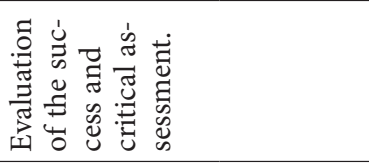 } & & 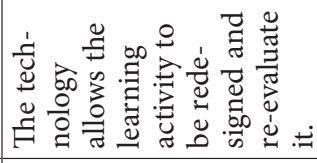 \\
\hline 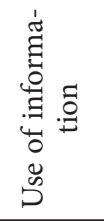 & \multicolumn{2}{|l|}{ 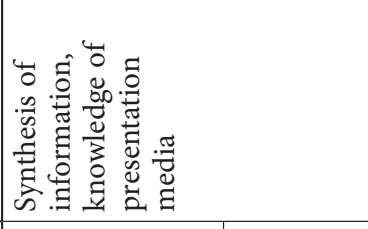 } & 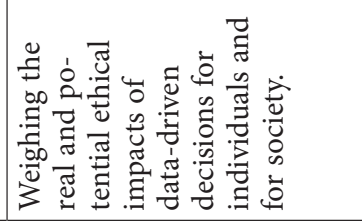 & \multirow{2}{*}{ 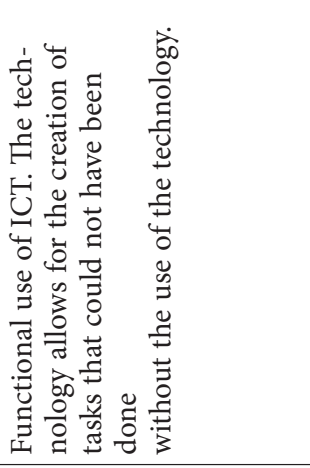 } \\
\hline 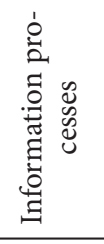 & 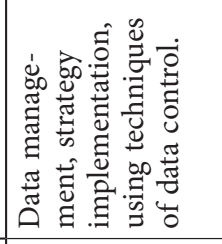 & 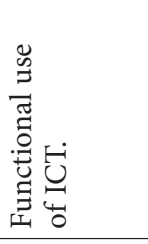 & 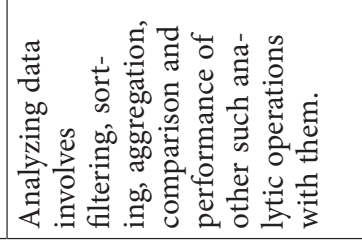 & \\
\hline 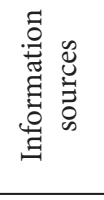 & \multicolumn{3}{|l|}{ 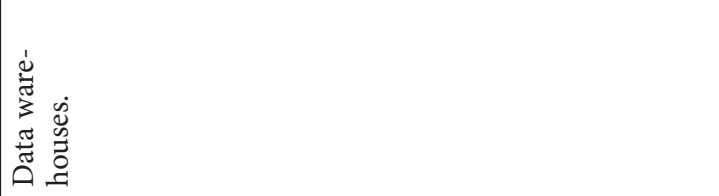 } & \multirow{2}{*}{ 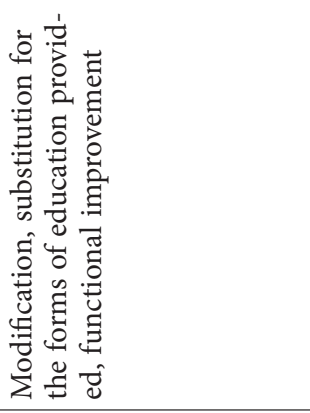 } \\
\hline 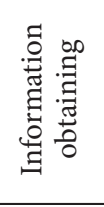 & 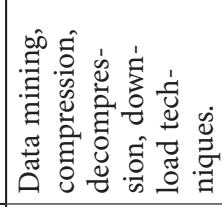 & 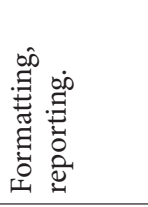 & 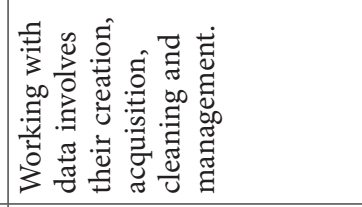 & \\
\hline \multirow{2}{*}{ 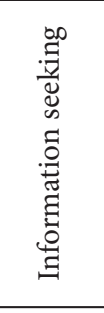 } & \multirow{3}{*}{ 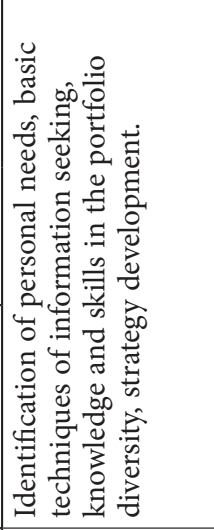 } & \multirow{3}{*}{ 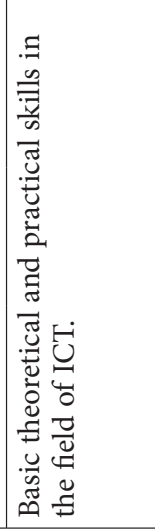 } & 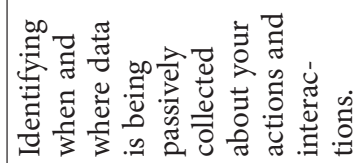 & \multirow{3}{*}{ 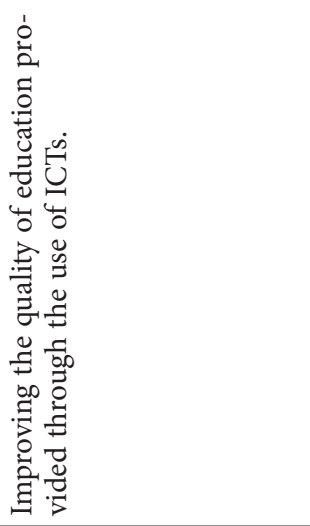 } \\
\hline & & & 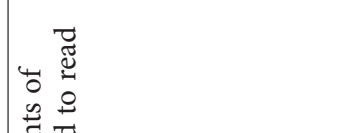 & \\
\hline 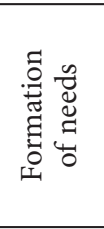 & & & 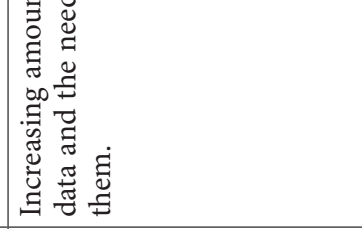 & \\
\hline 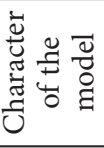 & \multicolumn{2}{|l|}{ 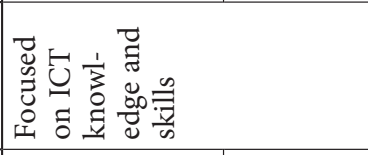 } & 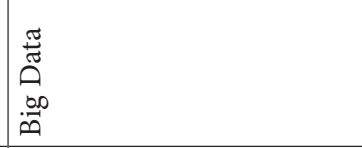 & 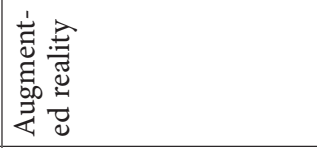 \\
\hline $\begin{array}{l}\vec{\nabla} \\
\frac{\overrightarrow{0}}{\Sigma}\end{array}$ & 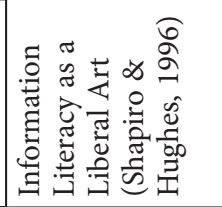 & 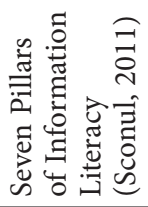 & 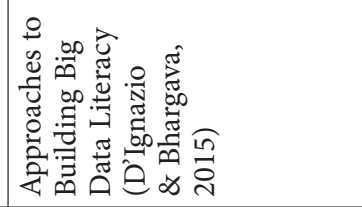 & 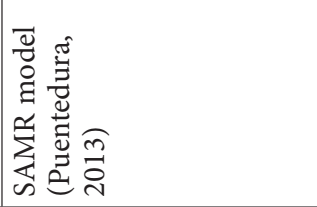 \\
\hline
\end{tabular}


Based on the impact assessment of individual variables an information literacy model can be compiled.

After summarising the literature review of the foreign and domestic authors, we generally define that there are 7 areas that can be used to explore information literacy, which originate from homogeneous and heterogeneous features of the analysed models (Table 2): Formation of information needs, Information seeking, Information obtaining, Information sources, Information processes, Use of information, Evaluation (review).

Several connections, as well as disparities, can be found between the analysed models in different areas. The comparison of models and their characteristics are presented in the following table. The contents for the determined areas of information literacy practice are not defined for some models. It can be easily seen from the aggregate form - the models of focus on the skills for working with ICTs and the models which are of the cognitive (aware and unaware) process nature. The models are grouped according to their characters and the common features are graphically distinguished and combined. The models that focus on ICT knowledge and skills and the heterogeneous models that cover several areas of the information literacy have the most common features. The intersection is in the areas of searching, obtaining information and information sources. The process models merge in the evaluation area. The homogeneous features are not identified in the competence models.

The areas of managers' education in the field of information and communication technology are detected from the results of the information literacy model comparison.

Major disparities between individual models are in the understanding of in formation literacy: knowledge versus practical skills. The ACRL (ALA, 2000) model divides the information literacy into five areas that contain the cognitive and technological aspects of information behaviour and thus focuses on the educational process. The process model BIG6 (Wolf et al., 2003) leads to the systematic access to information related to critical thinking and skills. It focuses on the information literacy as the qualified access to the operational and informational problem-solving. The 5-As model (Jukes et al., 2000) forms the functional information and technological literacy. It relies on the process framework for lifelong learning. It focuses on the skills and the techniques related to the information literacy. The Seven Faces of Information Literacy (Bruce, 2003) presents the seven information literacy approaches. The model presents the literacy development opportunities in several areas simultaneously and independently. The model provides the interactive image of the knowledge perception and the skills in the individual pillars, where the information literate manager may become the expert in the different pillars independently. The Information Literacy Landscape (Bent et al., 2007) is the broadly conceived model that involves both macro and micro level of manager's information literacy, which is influenced by external, as well as internal factors. It is rather an open mind map. Historical aspects, philosophical perspectives of the future state, as well as the definition of knowledge and skills, these all describe the model of Information Literacy as a Liberal Art (Shapiro \& Hughes, 1996). The model deduces the requirements on knowledge and practical skills of hardware and software. The Model of the Information Search Process by Kuhlthau (2004) brings the constructive perspective on the information literacy. It presents cognitive and technical processes and specific strategies and techniques of using information. A specific group is formed by models dealing with the Big Data literacy model 
and the Augmented Reality. The emerging field of data literacy has many actors working on various topics and approaches. Some are building networks of trainers to support the growth of the open data field. Data literacy includes the ability to read, work with, analyse and argue with data (Bhargava \& D'Ignazio, 2015). Reading data involves understanding what data is, and what aspects of the world it represents. Working with data involves their creation, acquisition, cleaning, and management. Analyzing data involves filtering, sorting, aggregation, comparison and performance of other such analytic operations with them. Arguing with data involves using data to support a larger narrative intended to communicate some message to a particular audience. Authors (D’Ignazio \& Bhargava, 2015) argue for including three more points for an extended definition of Big Data literacy: Identifying when and where data are being passively collected about your actions and interactions. Understanding the algorithmic manipulations performed on large sets of data to identify patterns. Weighing the real and potential ethical impacts of data-driven decisions for individuals and for society. The Substitution Augmentation Modification Redefinition Model (SAMR) (Puentedura, 2006) provides a framework that can be used to classify and evaluate M-Learning activities. The SAMR offers a method of seeing how computer technology might impact teaching and learning. It also shows a progression that adopters of educational technology often follow as they progress through teaching and learning with technology. Model that includes four levels of technology integration (substitution, augmentation, modification, and redefinition) and provides a framework to support educators and instructional designers in creating optimal learning experiences using mobile devices in education (Romrell, Kidder, \& Wood, 2014).

\section{Methodology}

We are looking at the information literacy index, which consists of the skills and the knowledge in seventy indicators segmented into four groups according to applicability: hardware, software (application, operational), communication, information. Aggregate information literacy (AIL) is the arithmetic mean of partial indices: the literacy index in working with the operating system, the literacy index in working with the application system, the hardware literacy index, the literacy index in information work and the literacy index in communication ability. The value of this index is in the scale of $0-1$ points. The higher the value, the higher the level of literacy. Each of them has partial indicators, only the number. After ascertaining the level of the information literacy index, we examined which variables have a significant impact on this index. We examined the influence of the factors in the table in theory. The information literacy index does not have a prescribed structure. Each survey that has been carried out so far has consisted of indicators that, according to the authors, best reflected the requirements of practice. Chetty (Chetty et al., 2017) emphasises that the digital literacy index needs to be structured in an agile manner, responsive to the changing needs of employers. Thus, the definition used to produce an internationally comparable index in the current year will differ from future iterations of the measurement based on the changing needs of the labour market. At the same time in designing AIL we applied the methodology (Rosa, 2013) that used the two complementary dimensions defined above: technical and operational skills in ICT and information skills in ICTs. According to the author, the index must 
be designed on the basis of theoretical backgrounds, current business practice requirements, and consultation with practice, which we followed. In the Slovak Republic, information and digital literacy of the population is examined by the Institute for Public Affairs using an index (Velšic, 2010, 2015) that includes 28 indicators measuring the level of work with hardware, software and electronic communication. Eurostat used an index to measure information literacy and digital literacy of the entire population of the Slovak Republic that included six indicators of skills graded according to their demandingness (Eurostat, 2013). In designing AIL, we started out from the theoretical backgrounds of already conducted domestic and foreign surveys and pushing requirements of managers and the business practice in Slovakia, which was preceded by extensive expert consultations, as the survey of information literacy of managers in the Slovak Republic has not been implemented.

The attitude toward education in information technologies was measured by 5 point Likert scale, where 1 was labelled as "negative" and 5 as "positive". From the answers we created two categories of respondents: those with negative or ambivalent attitude $(1,2,3)$ and those with positive attitude. Then we measured how different incentives influence those attitudes. There were six different incentives investigated: interest in personal growth, building career (ambition), request from employer, interest in new trends in IT, possibility of better work post, and recommendation from friend and all were measured by 10 point Likert scale.

The research part of the paper was achieved by the evaluation of a questionnaire survey, in particular a partial empirical observation method. The target group of the survey were Slovak managers at different levels and sectors: public and private sector, manufacturing and non-manufacturing sectors; without dividing organisations according to legal forms. The questionnaires were distributed to 200 managers using electronic communication.

The process of designing the questionnaire was based on the analysis of individual problem areas and the justified structure, content and criteria validity. Reliability and accuracy of the questionnaire was determined by the following factors: frequency of items, homogeneity and complexity of the tasks (Field, 2009). In the accompanying letter, the addressed managers were assured of compliance with ethical principles: confidentiality of information and anonymity. The questionnaires were distributed in September 2013 to the managers at all levels of management covering the entire Slovak Republic. The data collection was completed in June 2014. The return of the questionnaires amounted to 180 respondents, which formed a base for the partial quantitative analysis. The representativeness of the sample was provided by regional balance, where sample was from all Slovak regions. The structure of the sample by the sectors approximates the distribution of enterprises in the national economy (Statistical Classification of Economic Activities - SK NACE). The respondents replied to listed questions and recorded the literacy rate at each of the analysed instruments.

The survey covered the managers of enterprises and organisations. $66.11 \%$ were the managers of non-manufacturing and $33.89 \%$ of manufacturing enterprises and organisations. The businesses of commercial enterprises were represented the most $-80.00 \%$.

The managers of individual enterprises were segmented into three groups according to their job position: 1 - Operational managers - 32.22\%; 2 - Tactical managers - 42.78\%; 3 - Top managers $-25.00 \%$. This criterion was often used in various statistical analyses. The managers most often achieved the Master's degree $-69.44 \%$. 
The managers were divided into five age groups. The first group: $18-25$ years $-5.56 \%$; the second group: 26 - 35 years $-37.22 \%$; the third group: 36 - 45 years $-27.22 \%$; the fourth group: $46-55$ years $-26.11 \%$; and the fifth group: $56-65$ years $-3.89 \%$. The age group was compared with the field of education. The managers' most common field of education was economics, management and business $-48.33 \%$.

The normal distribution of data was tested using the Levene' test and KolgomorovSmirnov test. For further analysis of normally distributed data T-tests and Anova with the Bonferoniho Correction were used. Data that did not meet the condition of the normal distribution were tested by the Mann-Whitney test and the Kruskal-Wallis test. The methods of the statistical system were used to test the hypothesis. The quantitative analysis was carried out using the SPSS Statistics software.

To fulfil all the conditions for regression analysis we performed Durbin-Watson test, tests for multi-colinearity, also residuals distribution plots, and measuring distance by Cook's distance and Mahalanobis distance, extreme cases were also analysed.

Based on these methods we evaluate the current state of the issue and design the model of managers' information literacy by the methods of analogy and logical scientific abstraction. The model reflects determinants and current demands placed on the ICT managers. A diagram of the model is qualitative because the principle is based on the analysis of the information literacy phenomena, a disclosure of elementary components and a definition of mutual relations between them. Characteristics of a holistic structure and an interpretation of meaning and functioning are an important part as well.

\section{Research results}

Manager's digital literacy and the use of individual ICT tools are analysed in the following aggregated groups. Values of each group's partial indicators are indicated in the following table. The surveyed managers recorded their own level of digital literacy on a scale from 0 to 100 points. The results of the statistical analysis show that the level of managers' digital literacy of the Slovak enterprises in working with hardware is 0.67 points. In this area, the managers achieve the best results among the monitored indicators. Consequently, the managers reach the best results in the digital literacy index of communication -0.58 points. The digital literacy level in working with information is 0.55 points. The lowest results are achieved by the managers in skills and knowledge of software (operating software -0.58 points and application software -0.44 points). Finally, the aggregate information literacy (AIL) index of Slovak managers reaches 0.58 points (Bolek et al., 2016). AIL is the arithmetic mean of partial indices: the literacy index in working with the operating system, the literacy index in working with the application system, the hardware literacy index, the literacy index in information work, and the literacy index in communication ability. The value of this index is in the scale of $0-1$ points. The higher the value, the higher the level of literacy.

After quantifying the level of information literacy of managers in the Slovak Republic, we found the statistical significance of the influence of individual factors (Table 3) on the level of information literacy. The standard of data sharing was tested through the Levene test. Data were normally distributed (Levene statistic $p>0.05$ ). One - Way Anova parametric test with 
Bonferroni correction, whose values were significant, was applied.

On the basis of the methodology for the model determination, we investigated which variables enter into the model and have a statistically significant effect on the model. Many variables enter into the information literacy model, where we detected their correlation to the aggregate index of information literacy.

Table 3. Results of the correlation analysis (source: own processing)

\begin{tabular}{|l|l|c|}
\hline \multirow{2}{*}{ Factors } & AIL \\
\hline \multirow{3}{*}{ ICT position } & Pearson Correlation & $0.189^{*}$ \\
\cline { 2 - 3 } & Sig. (2-tailed) & 0.011 \\
\hline \multirow{3}{*}{ Finance } & Pearson Correlation & $0.160^{*}$ \\
\cline { 2 - 3 } & Sig. (2-tailed) & 0.032 \\
\hline \multirow{3}{*}{ Processes } & Pearson Correlation & $0.166^{*}$ \\
\cline { 2 - 3 } & Sig. (2-tailed) & 0.026 \\
\hline Evaluation & Pearson Correlation & $0.151^{*}$ \\
\cline { 2 - 3 } & Sig. (2-tailed) & 0.043 \\
\hline \multirow{3}{*}{ Productivity } & Pearson Correlation & $0.150^{*}$ \\
\cline { 2 - 3 } & Sig. (2-tailed) & 0.044 \\
\hline \multirow{2}{*}{ Trends } & Pearson Correlation & $0.239^{* *}$ \\
\cline { 2 - 3 } & Sig. (2-tailed) & 0.001 \\
\hline Attitude & Pearson Correlation & $0.298^{* *}$ \\
\cline { 2 - 3 } & Sig. (2-tailed) & 0.000 \\
\hline Size & Pearson Correlation & $0.235^{* *}$ \\
\cline { 2 - 3 } & Sig. (2-tailed) & 0.001 \\
\hline & Pearson Correlation & $0.024^{*}$ \\
\cline { 2 - 3 } & Sig. (2-tailed) & 0.746 \\
\hline
\end{tabular}

Note: ${ }^{\star}$ Correlation is significant at 0.05 level (2-tailed); ${ }^{* *}$ Correlation is significant at 0.01 level (2-tailed).

Only those variables enter into the model, which correlate with the aggregate index of information literacy - the $p$-value $\leq 0.05$.

The aggregate literacy index is predicted by the partial indices: the literacy index of operating system; application system; hardware; information; and communication. Together with these indicators, the following constants enter the statistically significant model $p<0.000$ at the significance level $p=0.05$ : ICT position viewed by a manager; intensity of ICT usage in employment; business size; effects from the use of ICT - financial savings and cost reduction; making business processes more effective; better financial evaluation of managers using ICT; and increasing labour productivity by applying ICT products. Personal characteristics of a manager belong to the model as well: interest in new ICT trends and managers' attitude towards ICT. The individual variables are assessed on a point scale.

Even if the model is statistically significant at the significance level $p=0.05$, it explains up to $11.90 \%$ of the index of information literacy. 
Some of the variables: ICT position; Intensity; Size; Processes; Evaluation; Productivity; and Attitude do not have a significant effect at the significance level of $p=0.05$. Therefore, it is necessary to eliminate and reduce these variables and to design a modified model. By removing these variables, the modified model that is statistically significant at $p=0.05$ is designed.

The aggregate index of literacy predicts the two variables that enter the statistically significant model $p<0.000$ at the significance level of $p=0.05$. The first variable represents the interest of managers in new ICT trends: the standardised $\beta=0.291 ; t(2.179)=4.102$; $p<0.000$; but it explains only a small proportion of the variance $R^{2}=0.102 ; F(2.179)=$ 11.147; $p<0.000$. The second variable resulting from the use of ICTs is financial savings and cost reduction: the standardised $\beta=0.152 ; t(2.179)=2.144 ; p=0.033$; but it explains only a small proportion of the variance $R^{2}=0.102 ; F(2$. 179) $=11.147 ; p=0.033$. The results of the analysis show (Figure 1) that the model is significant $p<0.000$ at the significance level of $\alpha=0.05$. The model explains $10.20 \%$ of the variance $\left(R^{2}=0.102\right)$. Up to $10.20 \%$ of the points of managers' information literacy are explained by these variables.

The statistical significance's verification of the variables entering the model is confirmed by the following graph (Figure 2).
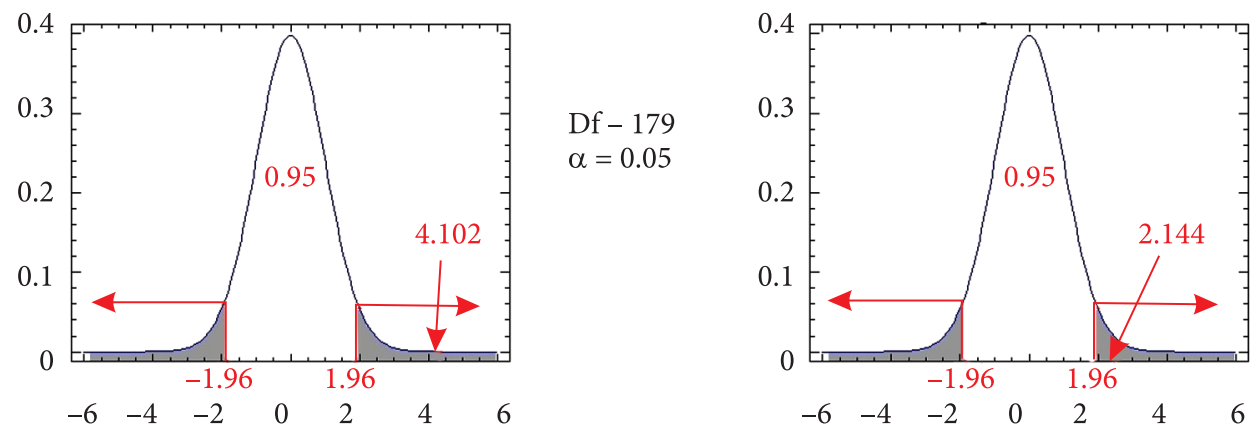

Figure 1. Verification of the model variables (ICT trends - left; Finance - right)

(source: own processing)

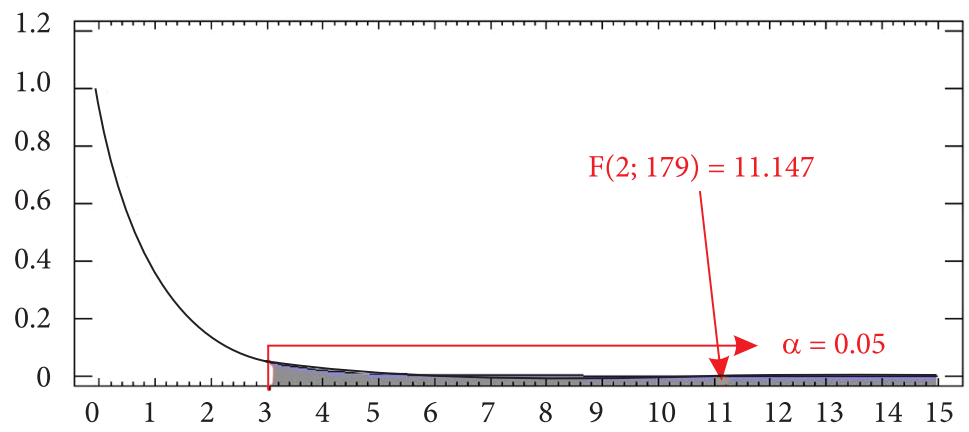

Figure 2. Verification of the model (source: own processing) 
To ensure normality of distribution we calculated Kolgomorov-Smirnov test for Aggregate index of literacy and we found that data were normally distributed $Z=0.64 ; p=0.81$, using appropriate methods.

Diagnostics test was used to confirm proper methods (regression analysis). We found that our data were not influenced by extreme cases (only 3 cases from all sample with standardized residuals lower -2 ), multicollinearity was absent $(\mathrm{VIF}=1.002$, Tolerance $=0.99$ ), residuals were uncorrelated (Durbin-Watson test $=1.99$ ), scatterplots showed perfect distribution between regression standardised residuals and predicted value. Finally we did not found for any case in our sample Cook's distance greater than 1 and Mahalanobis distance higher than 15. Therefore all requirements for regression analysis were met and our results from this point are valid.

On the basis of the Anova model's results and the general equation $\left(Y=b_{0}+b_{1} x\right)$, we have developed the equation as follows:

$$
A I L(x)=36.487+1.783 \cdot \text { Trends }+1.337 \cdot \text { Finance. }
$$

If the managers' interest in the new ICT trends increases by 1 point, the aggregate index of literacy increases by 1.783 points; and if the managers' financial motivation increases by 1 point, the aggregate index of literacy increases by 1.337 points. Of course, the aggregate index of literacy is predicted by the values of the partial indices: the literacy index of operating system; application system; hardware; information; communication and their directly proportional impact on the aggregate index.

We also used the hierarchical binary logistic regression with the forward method to investigate how different incentives influence attitude toward education in IT. From all incentives only two were significant: interests in new trends in IT and the possibility of a job position, but these two predictors did not interact with each other and the interaction was insignificant.

In the first block only interests in new trends were used as a predictor with the following results: $\beta=0.323^{* * *}, S E=0.071, \chi^{2}(1)=24.23^{* * *}, R^{2}=0.193$ (all $R^{2}$ in this block are calculated by Nagelkerke's method). In the second block also the possibility of a better job position was added and the results for the interests were: $\beta=0.278^{* * *}, S E=0.073$ and for the possibility of job position $\beta=0.147^{* * *}, S E=0.076$. The second block brought more variability and the model was better $\chi^{2}(1)=27.98^{* * *}, R^{2}=0.22$.

If respondents scored 10 points (maximum) in the interest in new trends in IT and also 10 (again maximum) in the possibility of job position, the predicted probability of being labelled as positive attitude in the group was $95.3 \%$, compared to $22.5 \%$ if respondents scored 0 for interests and possibility of work post.

\section{Discussion}

The aggregate index of information literacy consists of the partial indices of digital literacy: hardware, software, information, and communication. The aggregate index of information literacy is significantly affected by: the managers' interest in the new ICT trends; the financial education in the ICT field; the managers' financial motivation; and the cost savings 
from using available ICTs in enterprises. The verification of the variables in the model confirmed that the significant impact on raising the level of information literacy of the managers is financially valued, which is also considered important in the study Lăzăroiu (2015), the manager's interest in the area of information and communication technologies and trends in this field (White, 2008; Wermann et al., 2015; Majumdar, 2015; Schrum et al., 2015; El Kadiri et al., 2016) and the manager's attitude itself towards education and information and communication technologies (Shaw \& Marlow, 1999; Ritchie \& Brindley, 2005; Fulantelli \& Allegra, 2003; Fu, 2013). Other variables did not have a statistically significant influence on the manager's literacy level.

Based on the current state of knowledge, the comparison of the information literacy models, the survey analysis of the managers and the definition of the information literacy concept, the process model of information literacy in managers' education have been designed. We have proposed a qualitative model (Figure 3), which has been absent in the Slovak Republic, based on the theoretical origins and quantitative statistical analyses. Information literacy is defined as the ability to identify the need for information, to search, obtain and process information using available and suitable ICT instruments; and to assess and obtain information in the most efficient way. We perceive digital literacy as a part of information literacy. The information literacy model presents 6 blocks. Managers' education in these blocks creates the synergy effect on managers' information literacy, which is affected by personal attributes and managers' surroundings.

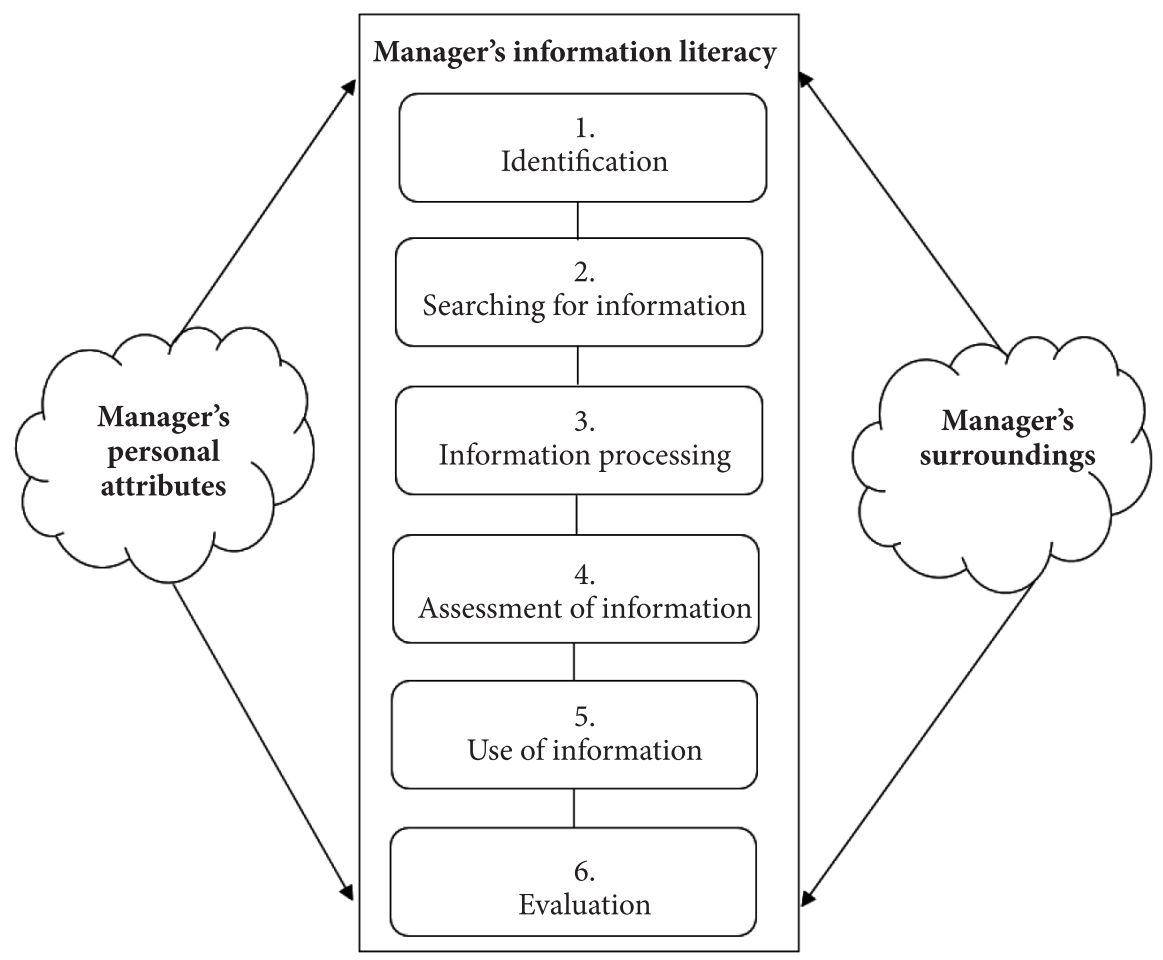

Figure 3. The Model of Manager Information Literacy (source: own processing) 
1. Identification of the need and a raised issue, a definition of information required and a definition of specific information needed. It is the ability to specify the nature and the need for information. A manager knows how to orient himself in published (available) and unpublished information, and at the same time he/she can also identify lack of knowledge in a specific field. The manager uses conceptual and practical ICT tools applicable in regular or professional life.

2. Searching for information refers to the ability of accessing information. The manager must be able to find and obtain information from a source where it is situated. He/she suitably integrates cognitive processes (evaluation on the basis of certain criteria, specifying the nature and the extent of information) and non-cognitive processes (confusion) during an information search. The manager effectively uses techniques and ICT to mine information from various sources in the ethical way. He/she knows to identify available tools for the search and formats of information.

3. Information processing includes knowledge and cooperation of a set of technology skills and cognitive processes. The manager must be sufficiently literate in techniques of providing and creating data warehouses, relevant data mining from the data warehouses and digital libraries, reporting, and their flexible use, compression and decompression.

4. Assessment of information represents its analysis and critical evaluation. Integration of cognitive processes is essential. Information is selected and extracted in this block. Furthermore, it starts to create data and information for decision-making and a knowledge base. The literate manager is able to evaluate the information, assess its relevance and credibility. He/she is able to summarise and critically assess his/her own and the others' findings.

5. Use of information is a synthesis of information to meet an objective and to satisfy information needs. An information literate manager skilfully creates consistent units from analytical information. By skills of information sharing, storing, and working with individual presentation media, the manager actively accesses dissemination of information, or he/she integrates new information into the context of current knowledge. If the manager creates new data and information, it is necessary to work with intuition and creativity. The manager must understand standards of managing information. He/she is good at using appropriate application software and knows how to use a technology for data management.

6. Evaluation means constant monitoring, correct data management, evaluation of a final result as well as the whole implementation process using intellectual, mechanical and technological tools. Assessment capabilities of the final result, critical assessment and subsequent feedback are necessary.

If the manager wants to be information literate at a satisfactory level, it is desirable that he/she is educated in the presented blocks. Information literacy is affected by two separate areas as follows:

Manager's personal attributes may be of an internal or external origin. The most important elements that increase manager's information literacy are his/her interest in personal growth, ambition, personal attitude towards ICTs and his/her interest in new trends in this field. Attitude towards learning has an irreplaceable position together with teaching styles, an intellect, personal values, skills and managers' competences. 
Manager's surroundings consist of individual links between elements that may directly affect the manager's information literacy. The most important elements of the manager's surroundings that affect its information literacy include attitude and requirements of a labour market and an employer towards the manager's information literacy: educational requirements; an education support system; a strategic business plan towards information literacy; employer's support of ICTs (purchase, education); and employer's and employee's participation in education support. The manager's surroundings create an education system - formal and informal education; experience with quality ICT courses; promotion of academic institutions; financial requirements; a family and friends.

To date, a survey focused on information literacy of managers has not been conducted in the Slovak Republic. From research we identified the level of information literacy of managers in the Slovak Republic and we identified significant factors that affect this level. Model variables were introduced such has ICT position, intensity, finance, processes, evaluation, productivity, trends, attitude, size. The variables were examined by the individual authors, which are presented in theoretical sources. Each variable has its justification in the research model and affects information literacy. The research conducted among managers in the Slovak Republic confirmed the statistical significance of two variables that have a significant impact on the manager's literacy and lead to an increase in its level.

The interest in trends and actual trends in the field of ICT themselves are an important element that can influence the knowledge and skills of managers and their information literacy, which is in line with the statement by several authors (Wermann et al., 2015; Majumdar, 2015; Schrum et al., 2015; El Kadiri et al., 2016). The motivator leading to higher literacy levels is also the manager's remuneration. Higher remuneration motivates managers to educate themselves in ICTs, increasing the level of their information literacy. We can say that business practice requires managers to be sufficiently information literate. Therefore, it is necessary to continuously learn in the field of ICTs, whether in the form of graduate, postgraduate or lifelong learning. The basis of information education are all levels of school, while universities play the key role in preparing the students - future professionals for practice in the area of computer science and ICTs. Given the dynamics of development in this area, it is necessary to educate managers after completing their studies in schools and involve them in lifelong learning, which is usually organised by universities and educational institutions. Lifelong learning includes all the activities that take place throughout life with the aim of improving knowledge, skills and abilities. Greater attractiveness on the labour market, in terms of company practices, will be with those who have fully understood the importance of ICTs. Those who did not understand the function of ICTs can find themselves in social isolation.

Due to the lack of a qualitative model of information literacy of managers, we propose a model of information literacy of managers taking into account qualitative results, which will be submitted also to the Association of Lifelong Learning of Adults in the field of ICT education in the Slovak Republic. The model is based on 7 areas in which we analysed the models of the individual authors on the theoretical basis. The model includes links to the models focused on ICT knowledge and skills (Shapiro \& Hughes, 1996; Sconul, 2011), as a certain process of building information literacy as presented by the process models (Wolf et al., 2003; Kuhlthau, 2004). However, the model proposed by us also takes into account developments 
in the field of ICTs and requirements for the knowledge and the skills of managers. Their education is also necesary in the area of the Big Data area, as the concept of the model claims (D'Ignazio \& Bhargava, 2015). Today, the challenge stimulating the development of new approaches and innovations in this area is, above all, the enormous pace of generating new and new data that need to be processed and exploited in terms of their potential to the maximum. In the past, data analysis was a relatively static matter. Companies get a lot of unnecessary data, which must go through selection. The most important solution is to improve processes to obtain appropriate data that will provide the company managers with the most relevant management information. With the massive take-up of mobile devices, social networks, hardware degradation and cloud services, the area of data generation and their potential use is changing as well. The development of new ICTs may also change the wellestablished practices and methods of education. Based on the SAMAR model (Puentedura, 2006), ICTs can be involved in the learning process, expand learning with new areas, and thus achieve an added value.

\section{Conclusions}

Information and ICTs, which represent essential parts of a business infrastructure, are the driving forces of the current modern society. Their development influences economic environment by a substantial degree and ranks among factors of business prosperity and competitiveness. Nowadays, it is not possible to manage enterprises, organisation and take professional decisions without information and the use of ICT. Managers of various organisations need relevant information for effective management. Such information is essential for correct decision-making. In all organisations of the public, cooperative or private sector, the managers are active in these categories: operational, tactical and top managers. They all have an important mission - to affect the organisations and their results.

An important means of shaping managers' skills is continuing education. The top management is aware of the fact that the continuing education of managers in any area of social life is essential. The managers must possess the knowledge and skills applied not just to manage organisations, but also to strategic decision-making in important matters in order to be able to detect new threats, opportunities and risks in a competitive environment. It is not enough to know how to use tools of information and communication technology, but it is also necessary to improve qualifications and education in the field of information security, because a lot of security incidents are linked to the insufficient level of expertise. Information literacy of managers was measured by the aggregate information literacy index. The research identified the question of how individual factors (based on the theoretical background) influence this index. From the results of the analyses (statistical methods, linear regression) it can be concluded that the significant impact on AIL has two factors, namely the interest in trends and current trends in the field of ICT and finance. The incentive leading to higher literacy levels is also the manager's remuneration.

At the present time, enterprises and organisations need an informed, creative, independent, communicative, adaptable and highly trained manager. But those who want to become one need to constantly improve through lifelong learning including self-education. This 
assumption is particularly truthful for the operational, tactical and top managers. Regarding the incentives of ICT managers' training, we have identified a research question as to which incentives influence the training of managers in this area. Based on analyses and statistical evaluation of the hierarchical binary logistic regression with the forward method, we note that from all incentives only two were significant: interest in new trends in IT and the possibility of a job position, but these two predictors did not interact with each other and the interaction was insignificant.

The Slovak Republic has until now lacked a survey focused on information literacy of managers. Population-specific researches are carried out. Our proposed model of managers' information literacy is applicable not only in corporate practice and lifelong learning, but also in the pedagogical process itself, as it reveals the process steps leading to the increase of information literacy.

Our contribution to literature is mainly empirical. We have explored an area that is relatively unexplored in professional literature, and our research can be considered as a basic source of information for a future, more detailed and specific research in the particular field.

The implemented study, however, has certain limits. The survey was conducted in the Slovak Republic. To date, a survey focused on the level of digital and information literacy of managers has not been conducted in the Slovak Republic. Therefore the comparison of the results is not possible. However, there is room for future direction and development of research. Perform this survey at certain time intervals and compare survey results and analyse developments with the impact on business practice, the school system, graduate and postgraduate education, lifelong learning and the preparation of future managers. A certain limit of the research is also the absence of specific research conducted abroad for this specific group, managers, science and technology advances in the field of ICT and the ever-increasing requirements for the knowledge and skills of ICT managers. Therefore, it can be said that the future direction of research and measurement of information literacy is live, open, changing to current conditions and requirements of corporate practice. But it is also a good feedback for graduate and postgraduate education.

\section{Funding}

The research described in the paper was financially supported by the Slovak Grant Agency (VEGA) under grant No. 1/0436/17.

\section{Disclosure statement}

The authors declare that they has no competing financial, professional, or personal interests from other parties.

\section{References}

Acar, E., Kocak, I., Sey, Y., \& Arditi, D. (2005). Use of information and communication technologies by small and medium-sized enterprises (SMEs) in building construction. Construction Management and Economics, 23(7), 713-722. https://doi.org/10.1080/01446190500127112 
American Library Association. (2000). Information literacy competency standards for higher education. Retrieved from http://hdl.handle.net/11213/7668

Antlová, K. (2009). Motivation and barriers of ICT adoption in small and medium-sized enterprises. $E$ + M Ekonomie a management, (2), 140-155. Retrieved from http://www.ekonomie-management.cz/ download/1331826716_d7e9/11_antlova.pdf

Barba-Sánchez, V., del Pilar Martínez-Ruiz, M., \& Jiménez-Zarco, A. I. (2007). Drivers, benefits and challenges of ICT adoption by small and medium sized enterprises (SMEs): a literature review. Problems and Perspectives in Management, 5(1), 103. Retrieved from https://businessperspectives.org/ journals/problems-and-perspectives-in-management/issue-16/drivers-benefits-and-challenges-ofict-adoption-by-small-and-medium-sized-en-terprises-smes-a-literature-review

Behrens, S. J. (1994). A conceptual analysis and historical overview of information literacy. College \& Research Libraries, 55(4), 309-322. https://doi.org/10.5860/crl_55_04_309

Bent, M., \& Stubbings, R. (2011). The sconul Seven Pillars of Information Literacy. Core model for higher education. London: SCONUL Working Group on Information Literacy. Retrieved from https:// www.sconul.ac.uk/sites/default/files/documents/coremodel.pdf

Bent, M., Gannon-Leary, P., \& Webb, J. (2007). Information literacy in a researcher's learning life: the seven ages of research. New Review of Information Networking, 13(2), 81-99. https://doi.org/10.1080/13614570801899983

Bhargava, R., \& D'Ignazio, C. (2015). Designing tools and activities for data literacy learners. Paper presented at Workshop on Data Literacy, Webscience. Retrieved from https://dam-prod.media.mit. edu/x/2016/10/20/Designing-Tools-and-Activities-for-Data-Literacy-Learners.pdf

Bolek, V., Kokles, M., \& Korček, F. (2016). The Information literacy level of Slovak managers. In Vision 2020: Innovation Management, Development Sustainability And Competitive Economic Growth: Proceedings of the 28th International Business Information Management Association Conference, 9-10 November 2016, Seville, Spain (pp. 1100-1111).

Bruce, C. (2003, August 30). Seven faces of information literacy: Towards inviting students into new experiences. Paper presented at Higher Colleges of Technology, United Arab Emirates 2003 Annual Conference.

Cardona, M., Kretschmer, T., \& Strobel, T. (2013). ICT and productivity: conclusions from the empirical literature. Information Economics and Policy, 25(3), 109-125.

https://doi.org/10.1016/j.infoecopol.2012.12.002

Ceccobelli, M., Gitto, S., \& Mancuso, P. (2012). ICT capital and labour productivity growth: A nonparametric analysis of 14 OECD countries. Telecommunications Policy, 36(4), 282-292. https://doi.org/10.1016/j.telpol.2011.12.012

Chetty, K., Qigui, L., Gcora, N., Josie, J., Wenwei, L., \& Fang, C. (2017). Bridging the digital divide: measuring digital literacy. Economics: The Open-Access, Open-Assessment E-Journal, 69, 1-20. Retrieved from http://www.economics-ejournal.org/economics/discussionpapers/2017-69

Corso, M., Martini, A., Paolucci, E., \& Pellegrini, L. (2003). Knowledge management configurations in Italian small-to-medium enterprises. Integrated Manufacturing Systems, 14(1), 46-56. https://doi.org/10.1108/09576060310453344

Cuadrado-Roura, J. R., \& Garcia-Tabuenca, A. (2004). ICT policies for SMEs and regional disparities. The Spanish case. Entrepreneurship \& Regional Development, 16(1), 55-75. https://doi.org/10.1080/0898562042000205036

D’Ignazio, C., \& Bhargava, R. (2015). Approaches to Building Big Data Literacy. Paper presented at Proceedings of the Bloomberg Data for Good Exchange Conference. Retrieved from https://dam-prod. media.mit.edu/x/2016/10/20/Edu_D'Ignazio_52.pdf

De Silva, H., \& Ratnadiwakara, D. (2008). Using ICT to reduce transaction costs in agriculture through better communication: A case-study from Sri Lanka. LIRNEasia, Colombo, Sri Lanka. Retrieved from https://ssrn.com/abstract=1565184 
Dombrovská, M., Landová, H., \& Tichá, L. (2004). Informační gramotnost: Teorie a prax v ČR [Information literacy: Theory and practices in CR]. Knihovnicka revue, 15(1), 7-18. Retrieved from http:// full.nkp.cz/nkkr/NKKR0401/0401007.html (in Czech)

El Kadiri, S., Grabot, B., Thoben, K. D., Hribernik, K., Emmanouilidis, C., von Cieminski, G., \&Kiritsis, D. (2016). Current trends on ICT technologies for enterprise information systems. Computers in Industry, 79, 14-33. https://doi.org/10.1016/j.compind.2015.06.008

Eurostat. (2013). Information society statistics. Digital literacy, eSkills. Retrieved from http://epp.eurostat.ec.europa.eu/statistics_explained/index.php/Information_society_statistics

Field, A. (2009). Discovering statistics using SPSS. (3rd ed.). London: SAGE Publications Ltd.

Fu, J. S. (2013). ICT in education: A critical literature review and its implications. International Journal of Education and Development Using Information and Communication Technology, 9(1), 112-125. Retrieved from https://files.eric.ed.gov/fulltext/EJ1182651.pdf

Fuchs, M., Höpken, W., Föger, A., \& Kunz, M. (2010). E-business readiness, intensity, and impact: An Austrian destination management organization study. Journal of Travel Research, 49(2), 165-178. https://doi.org/10.1177/0047287509336469

Fulantelli, G., \& Allegra, M. (2003). Small company attitude towards ICT based solutions: some keyelements to improve it. Educational Technology \& Society, 6(1), 45-49. Retrieved from http://www. jstor.org/stable/jeductechsoci.6.1.45

Jukes, I., Dosaj, A., \& Macdonald, B. (2000). NetSavvy: Building Information literacy in the classroom. Corwin Press.

Kılıçaslan, Y., Sickles, R. C., Atay Kayış, A., \& Üçdoğruk Gürel, Y. (2017). Impact of ICT on the Productivity of the Firm: Evidence from Turkish Manufacturing. Journal of Productivity Analysis, 47(3), 277-289. https://doi.org/10.1007/s11123-017-0497-3

Kpodar, K., \& Andrianaivo, M. (2011). ICT, financial inclusion, and growth evidence from African countries (Working Paper No. 11/73). International Monetary Fund. Retrieved from https://www.imf. org/en/Publications/WP/Issues/2016/12/31/ICT-Financial-Inclusion-and-Growth-Evidence-fromAfrican-Countries-24771

Kuhlthau, C. C. (2004). Seeking meaning: A process approach to library and information services. Libraries Un ltd Incorporated.

Lăzăroiu, G. (2015). Employee motivation and job performance. Linguistic and Philosophical Investigations, 14(1), 97-102. Retrieved from https://www.deepdyve.com/lp/addleton-academic-publishers/ employee-motivation-and-job-performance-1yzcyBeS9U

Majumdar, S. (2015). Emerging Trends in ICT for Education \& Training. Retrieved from https://pdfs.semanticscholar.org/7dff/40e831d0560c5d0b99528ea9914913f4fb26.pdf?.ga=2.65450217.655283987. $1529392592-2990011.1529392592$

Manochehri, N., Al-Esmail, R., \& Ashrafi, R. (2012). Examining the impact of information and communication technologies (ICT) on enterprise practices: A preliminary perspective from Qatar. The Electronic Journal of Information Systems in Developing Countries, 51(1), 1-16. https://doi.org/10.1002/j.1681-4835.2012.tb00360.x

Modimogale, L., \& Kroeze, H. J. (2011). The role of ICT within Small and Medium Enterprises in Gauteng. Communications of the IBIMA, 2011(2011). Article ID 369288. https://doi.org/10.5171/2011.369288

Ongori, H., \& Migiro, S. O. (2010). Information and communication technologies adoption in SMEs: literature review. Journal of Chinese Entrepreneurship, 2(1), 93-104. https://doi.org/10.1108/17561391011019041

Puentedura, R. (2006). Transformation, technology, and education [Blog post]. Retrieved from http:// hippasus.com/resources/tte/

Ritchie, B., \& Brindley, C. (2005). ICT adoption by SMEs: implications for relationships and management. New Technology, Work and Employment, 20(3), 205-217. https://doi.org/10.1111/j.1468-005X.2005.00154.x 
Romrell, D., Kidder, L. C., \& Wood, E. (2014). The SAMR model as a framework for evaluating mLearning. Journal of Asynchronous Learning Networks, 18(2). https://doi.org/10.24059/olj.v18i2.435

Rosa Riberio, F. (2013). Proposal for a digital literacy index: results of the methodological formulation. Retrieved from: http://www.academia.edu/12017863/Proposal_for_a_digital_literacy_index_results_of_the_methodological_formulation

Saarenketo, S., Puumalainen, K., Kyläheiko, K., \& Kuivalainen, O. (2008). Linking knowledge and internationalization in small and medium-sized enterprises in the ICT sector. Technovation, 28(9), 591-601. https://doi.org/10.1016/j.technovation.2007.12.003

Sassi, S., \& Goaied, M. (2013). Financial development, ICT diffusion and economic growth: Lessons from MENA region. Telecommunications Policy, 37(4), 252-261. https://doi.org/10.1016/j.telpol.2012.12.004

Schrum, L., Davis, N., Jacobsen, M., Lund, A., Ferhan Odabasi, H., Voogt, J., \& Way, J. (2015). A Global Perspective: Current Trends and Issues in ICT for 21st Century Education. In AERA 2015 Conference Invited Panel for SIG TACTL. Retrieved from https://ir.canterbury.ac.nz/bitstream/ handle/10092/10943/12654731_AERA\%20International\%20panel_SIG_TACTL\%20Schrum\%20 Davis\%20et\%20al\%20May2015.pdf? sequence=1\&isAllowed $=y$

Sconul. (2011). Seven pillars of information literacy. Retrieved from http://www.sconul.ac.uk/sites/default/files/documents/doughnut.jpg

Shapiro, J. J., \& Hughes, S. K. (1996). Information literacy as a liberal art: enlightenment proposals for a new curriculum. Educom Review, 31(2). Retrieved from https://www.educause.edu/ir/library/ $\mathrm{html} / \mathrm{erm} / 31231 . \mathrm{html}$

Shaw, G., \& Marlow, N. (1999). The role of student learning styles, gender, attitudes and perceptions on information and communication technology assisted learning. Computers \& Education, 33(4), 223-234. https://doi.org/10.1016/S0360-1315(99)00020-2

Southern, A., \& Tilley, F. (2000). Small firms and information and communication technologies (ICTs): toward a typology of ICTs usage. New Technology Work and Employment, 15(2), 138-154. https://doi.org/10.1111/1468-005X.00070

Spiezia, V. (2012). ICT investments and productivity. OECD Journal: Economic Studies, 2012(1), 199211. https://doi.org/10.1787/eco_studies-2012-5k8xdhj4tv0t

Velšic, M. (2010). Digitálna gramotnost a trh práce - Výskumná správa [Digital literacy and the labor market - Research report]. Institute for Public Affairs. Retrieved from http://www.ivo.sk/buxus/ docs//vyskum/subor/DG_a_trh_prace.pdf ISBN 978-80-89345-27-4 (in Slovak).

Velšic, M. (2015). Digitálna gramotnost na Slovensku 2015 - Výskumná správa [Digital literacy in Slovakia 2015 - Research report]. Institute for Public Affairs. Retrieved from http://www.ivo.sk/buxus/ docs/vyskum/subor/Digitalna_gramotnost_2015.pdf (in Slovak).

Wermann, J., Kliesing, N., Colombo, A. W., \& Moraes, E. C. (2015, November 9-12). Impact of new ICT trends for the educational curriculum in the area of Industrial Automation and engineering. In IECON 2015 - 41st Annual Conference of the IEEE Industrial Electronics Society. Yokohama, Japan. IEEE. https://doi.org/10.1109/IECON.2015.7392667

White, G. K. (2008). ICT trends in education. Australian Council for Educational Research. Retrieved from https://research.acer.edu.au/digital_learning/2/

Wolf, S., Brush, T., \& Saye, J. (2003). The big six information skills as a metacognitive scaffold: a case study. School Library Media Research, 6, 1-24. Retrieved from http://www.ala.org/aasl/sites/ala.org. aasl/files/content/aaslpubsandjournals/slr/vol6/SLMR_BigSixInfoSkills_V6.pdf 